\title{
Monoclonal Antibodies against Plasmodium falciparum Circumsporozoite Protein
}

\author{
Min Zhang ${ }^{1,2,3}$, Rajakumar Mandraju ${ }^{1,4}$, Urvashi Rai ${ }^{1}$, Takayuki Shiratsuchi ${ }^{1,5}$ and \\ Moriya Tsuji ${ }^{1, *}$ \\ 1 HIV and Malaria Vaccine Program, Aaron Diamond AIDS Research Center, Affiliate of The Rockefeller \\ University, New York, NY 10016, USA; zhanmin@iu.edu (M.Z.); mandraju@gmail.com (R.M.); \\ urvashi.rai@gmail.com (U.R.); Shiratsuchi.Takayuki@hq.otsuka.co.jp (T.S.) \\ 3 Department of Pharmacology and Toxicology, Indiana University School of Medicine, Indianapolis, \\ IN 46202, USA \\ 4 Department of Immunology, UT Southwestern Medical Center Dallas, TX 75390, USA \\ 5 Otsuka Pharmaceutical Co., Ltd., Osaka 540-0021, Japan \\ * Correspondence: mtsuji@adarc.org; Tel.: +1-212-448-5021
}

Received: 10 May 2017; Accepted: 1 August 2017; Published: 23 August 2017

\begin{abstract}
Malaria is a mosquito-borne infectious disease caused by the parasite Plasmodium spp. Malaria continues to have a devastating impact on human health. Sporozoites are the infective forms of the parasite inside mosquito salivary glands. Circumsporozoite protein (CSP) is a major and immunodominant protective antigen on the surface of Plasmodium sporozoites. Here, we report a generation of specific monoclonal antibodies that recognize the central repeat and C-terminal regions of $P$. falciparum CSP. The monoclonal antibodies 3C1, 3C2, and 3D3-specific for the central repeat region-have higher titers and protective efficacies against challenge with sporozoites compared with 2A10, a gold standard monoclonal antibody that was generated in early 1980s.
\end{abstract}

Keywords: Plasmodium falciparum; circumsporozoite protein; CSP; monoclonal antibody; 2A10; 3C1; 3C2; 3D3

\section{Introduction}

In 2015, there were 214 million new cases of malaria (range 149-303 million) and an estimated 438,000 malaria deaths (range 236,000-635,000) worldwide [1]. Malaria is a mosquito-borne disease caused by the protozoan parasite, Plasmodium spp. Malaria is transmitted among humans by the bite of female mosquitoes of the genus Anopheles. The battle against malaria has been fought using a wide range of interventions, including insecticide-treated bed nets, indoor residual spraying, effective medicines, and vaccine [2-5]. However, emerging antimalarial drug resistance and insecticide resistance threaten malaria control and public health [6-8]. The only approved malaria vaccine is RTS,S/A01 (trade name Mosquirix) to date. RTS,S/A01 represents it's composed of P. falciparum CSP repeat region (R), T-cell epitopes (T) fused to the hepatitis B surface antigen (S) and assembled with un-fused copies of hepatitis B surface antigen, and a chemical adjuvant (AS01) is added to increase the immune system response. The efficacy of RTS,S/AS01 against all episodes of severe malaria is approximately $50 \%$ in young children in Africa [9-11]. A completely effective vaccine is not yet available for malaria. The novel vectored immunoprophylaxis, an adeno-associated virus-based technology to introduce effective antibody genes in mammalian host, has been added to currently available tools to control malaria [12]. A highly efficient neutralization antibody is one of the essential components of the vectored immunoprophylaxis [12]. Sporozoites are the infectious form of the parasites inside mosquito salivary glands. The circumsporozoite protein (CSP) is a major protein 
on the surface of Plasmodium sporozoites and an immunodominant protective antigen in irradiated sporozoites [13]. The overall structure of CSP is conserved among Plasmodium species, consisting of a species-specific central tandem repeat region flanked by conserved N-terminus and C-terminus [14]. The N-terminus is proteolytically processed during sporozoite invasion into host cells, unmasking the C-terminal cell-adhesive domain $[15,16]$. The C-terminus contains a thrombospondin repeat domain and $\mathrm{T}$ cell epitopes. The central repeat region, which is composed of approximately 30 tandem repeats of asn-ala-asn-pro (NANP), corresponds to highly immune-dominant B-cell epitopes [17,18].

The transmission of malaria from mosquito to mammalian host can be prevented by antibodies against CSP, such as the monoclonal antibody (mAb) 2A10 [12,19]. The mouse mAb 2A10 is directed against the central repeat region of $P$. falciparum CSP (PfCSP) [12,20-22]. The mouse mAb $2 \mathrm{~A} 10$ is a useful tool for the study of PfCSP in a mouse model. Delivery of adeno-associated virus expressing 2A10 into mice results in long-lived mAb expression and protection from sporozoite challenge. Vectored immunoprophylaxis provides an exciting new approach to the urgent goal of effective malaria control [12]. However, the mice expressing the CSP-specific mAb 2A10 lower than $1 \mathrm{mg} / \mathrm{mL}$ could not be completely protected [12]. Thus, highly potent CSP-specific antibodies are desired for the immunoprophylaxis to control this infectious disease. Here, we report a generation of novel and potent CSP-specific antibodies against PfCSP. In addition, we characterized the mAbs' subclasses, titers, and protections for sporozoite challenge. Importantly, the protective efficacies of $3 C 1,3 C 2$, and $3 \mathrm{D} 3$ were found to be better than the reference mAb 2A10.

\section{Materials and Methods}

\subsection{Expression and Purification of Recombinant PfCSP}

PfCSP coding sequence without glycosylphosphatidylinositol (GPI) anchor (GenBank: M19752.1) was amplified using Phusion ${ }^{\circledR}$ high fidelity DNA polymerase (Cat\#M0530S, New England Biolabs, Ipswich, MA, USA) with specific primers containing EcoR I and Not I restriction enzyme recognition sites. The PCR product was purified using Qiagen PCR cleanup kit (Qiagen, Germantown, MD, USA). Both the PCR product and pET20b vector were digested with restriction endonucleases EcoR I and Not I (New England Biolabs) according to the manufacturer's protocol. After gel purification, the digested PCR product was ligated into the linearized $\mathrm{pET} 20 \mathrm{~b}$ vector using Roche rapid DNA ligation kit (Cat. No. 11635379001, Roche, Branford, CT, USA), and then transformed into Top10F' chemically competent E. coli. (Invitrogen, Grand Island, NY, USA) and plated onto Luria-Bertani (LB) agar plates containing ampicillin. A single colony was picked from the plate and inoculated into LB broth plus ampicillin. The recombinant plasmid was purified from the overnight culture using Qiagen plasmid purification kit. The purified plasmid was validated by DNA sequencing and transformed into the BL21(DE3) strain for protein expression. When the culture reached an optical density (OD, $600 \mathrm{~nm}$ ) of 0.5-0.6, PfCSP expression was induced using IPTG $(1 \mathrm{mM})$ at $20{ }^{\circ} \mathrm{C}$. Then the overnight culture was pelleted by centrifugation and lysed with lysozyme buffer and followed by sonication. Lysate was cleared by centrifugation and the His-tagged PfCSP was purified using $\mathrm{Ni}^{2+}$-affinity chromatography (Qiagen, Germantown, MD, USA).

PfCSP purification: $25 \mathrm{~mL}$ of nickel nitrilotriacetic acid (Ni-NTA) agarose beads were loaded onto a $22 \mathrm{~mL}$ phenyl sepharose column (Pharmacia/Pfizer, New York, NY, USA), washed and equilibrated by $200 \mathrm{~mL}$ of His Elution Buffer (50 mM TRIS hydrochloride (Tris-HCl) (pH 8.0), $300 \mathrm{mM}$ imidazole, $50 \mathrm{mM} \mathrm{NaCl}, 0.1 \mathrm{mM}$ ethylenediaminetetraacetic acid (EDTA), and $1 \mathrm{mM}$ phenylmethane sulfonyl fluoride (PMSF) and $500 \mathrm{~mL}$ of His Binding Buffer (50 mM Tris- $\mathrm{HCl}$ (pH 8.0), $5 \mathrm{mM}$ imidazole. $100 \mathrm{mM}$ $\mathrm{NaCl}, 0.1 \mathrm{mM}$ EDTA, and $1 \mathrm{mM}$ PMSF). Then the clarified lysate from $1 \mathrm{~L}$ culture was added to the column and washed with $250 \mathrm{~mL}$ of His Binding Buffer followed by $500 \mathrm{~mL}$ of His Wash Buffer (50 mM Tris-HCl (pH 8.0), $20 \mathrm{mM}$ imidazole. $300 \mathrm{mM} \mathrm{NaCl}, 0.1 \mathrm{mM}$ EDTA, and $1 \mathrm{mM}$ PMSF). Then, the bound protein was eluted with $20 \times 15 \mathrm{~mL}$ of His Elution Buffer (50 mM Tris-HCl (pH 8.0), $200 \mathrm{mM}$ imidazole. $300 \mathrm{mM} \mathrm{NaCl}, 0.1 \mathrm{mM}$ EDTA, and $1 \mathrm{mM}$ PMSF). Proteins were resolved on sodium dodecyl 
sulfate polyacrylamide gel electrophoresis (SDS-PAGE) followed by Coomassie Brilliant Blue staining. Tris- $\mathrm{HCl}$, EDTA, and PMSF are from Sigma-Aldrich, St. Louis, MO, USA.

\subsection{Generation of Hybridomas}

The recombinant PfCSP was shipped to Green Mountain Antibodies, Inc. (Burlington, VT, USA) for the immunization of mice, followed by the fusion to generate monoclonal antibodies. Briefly, mice were primed with $50 \mu \mathrm{g}$ of PfCSP emulsified with complete Freund's adjuvant, followed by weekly immunization of $50 \mu \mathrm{g}$ of PfCSP emulsified with TiterMax ${ }^{\circledR}$ (Sigma-Aldrich, St. Louis, MO, USA) and SAS $^{\circledR}$ (Sigma-Aldrich) (alternate week). One week after administering seven doses of immunization, the lymph node was isolated. B cells were purified from using anti-B220 magnetic-activated cell sorting (MACS), and then fused with a mouse myeloma cell line. Cloning was achieved by limiting dilution. After re-cloning, positive clones that secrete immunoglobulin $\mathrm{G}(\mathrm{IgG})$ against the full-length PfCSP were selected by enzyme-linked immunosorbent assay (ELISA) (Table 1).

\subsection{ELISA Assay}

The ELISA plates were first coated with peptides representing PfCSP N-terminal, the central repeat, or C-terminal regions $(10 \mu \mathrm{g} / \mathrm{mL})$ and then blocked with $3 \%$ bovine serum albumin (BSA) in phosphate buffered saline with Tween-20 (PBST) (Table 2). MAbs were 10-fold diluted $(0.1-1000 \mathrm{ng} / \mathrm{mL})$ and added to the plates and incubated for $1 \mathrm{~h}$. After washing the plates, horseradish peroxidase (HRP)-conjugated goat anti-human IgG Fc Fragment was added. One hour later, tetramethylbenzidine (TMB) High Sensitivity Substrate was added, and ODs were read at $450 \mathrm{~nm}$. Peptide AIAWAKARARQGLEW was used as a negative control. The mAb 2A10 was used as a positive control $[19,23]$.

\subsection{Immuno-Fluorescence Assay}

$1 \times 10^{4}$ salivary gland PfCSP/Py sporozoites were loaded on MP biomedical multi-test glass slides (MP Biomedicals, Santa Ana, CA, USA). PfCSP/Py is an infectious P. yoelii parasite bearing a full length of $P$. falciparum circumsporozoite protein (25). After air drying at room temperature, the slides were fixed with $4 \%$ paraformaldehyde for $10 \mathrm{~min}$ at room temperature, and then blocked with $3 \%$ BSA in PBST. The mAbs were two-fold diluted from $1.31 \mathrm{mg} / \mathrm{mL}$ to $5 \mathrm{ng} / \mathrm{mL}$, and added to the PfCSP/Py sporozoites-coated wells on the slides for $45 \mathrm{~min}$. After washing with PBS containing $0.05 \%$ Tween-20 three times, the slides were incubated with Alexa Fluor 594 conjugate goat anti-mouse IgG $(\mathrm{H}+\mathrm{L})$ antibody. One hour later, the slides were washed and mounted in PBS containing $50 \%$ glycerol and $1 \%(w / v) p$-phenylenediamine to reduce bleaching.

\subsection{Sporozoite Neutralization Assays}

In vitro neutralization assays were conducted by pre-incubating $2 \times 10^{4} \mathrm{PfCSP} / \mathrm{Py}$ sporozoites with $100 \mu \mathrm{g} \mathrm{mAb}$ on ice for $45 \mathrm{~min}$, and then adding to $1 \times 10^{5}$ Hepa1- 6 cells. Forty-two hours post infection, liver stage parasite burden wear measured by quantitative polymerase chain reaction (qPCR) of P. yoelii 18S rRNA as previously described [24]. Mouse glyceraldehyde 3-phosphate dehydrogenase (GAPDH) was used as an internal control. In vivo neutralization assays were conducted by pre-incubating $50 \mathrm{PfCSP} / \mathrm{Py}$ sporozoites dissected from infected mosquito salivary glands with 5 or $50 \mu \mathrm{g} \mathrm{mAb}$ on ice for $45 \mathrm{~min}$, and then intravenously injecting into BALB/c mouse. The presence of parasite in blood was determined by Giemsa staining of the blood smear of the recipient mouse.

\subsection{Giemsa Stain}

Starting three days after sporozoite challenge, a drop of blood was collected from the mouse tail vein for thin blood smears on pre-cleaned glass slides. Thin blood smears were fixed with absolute 
methanol and then stained with diluted Giemsa stain $(1: 20, v / v)$ for $20 \mathrm{~min}$. \% parasitemia (\% of parasitized red blood cells among total red blood cells) were examined with a $100 \times$ oil immersion objective under the microscope.

\section{Results}

\subsection{Generation of Hybridomas}

PfCSP was expressed and purified from E. coli. (Figure 1), and then immunized BALB/c mice. The immune spleen cells from the mice producing anti-PfCSP antibodies were fused with myeloma cells, and six hybridoma cell lines (2D4, 3C1, 3C2, 3D3, 4C1, 4C6) were cloned. The mAbs 4C6 2D4 $3 \mathrm{D} 3$ were identified as belonging to subclass IgG1. The mAbs $3 \mathrm{C} 2$ and $4 \mathrm{C} 1$ were isotyped as IgG2b class. The $\mathrm{mAb} 3 \mathrm{C} 1$ belonged to subclass IgG3 (Table 1).

A

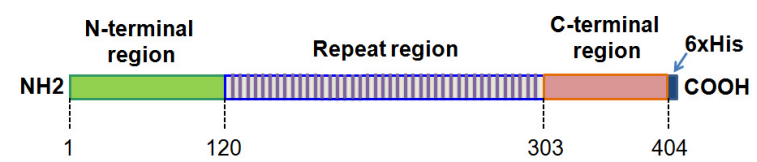

B
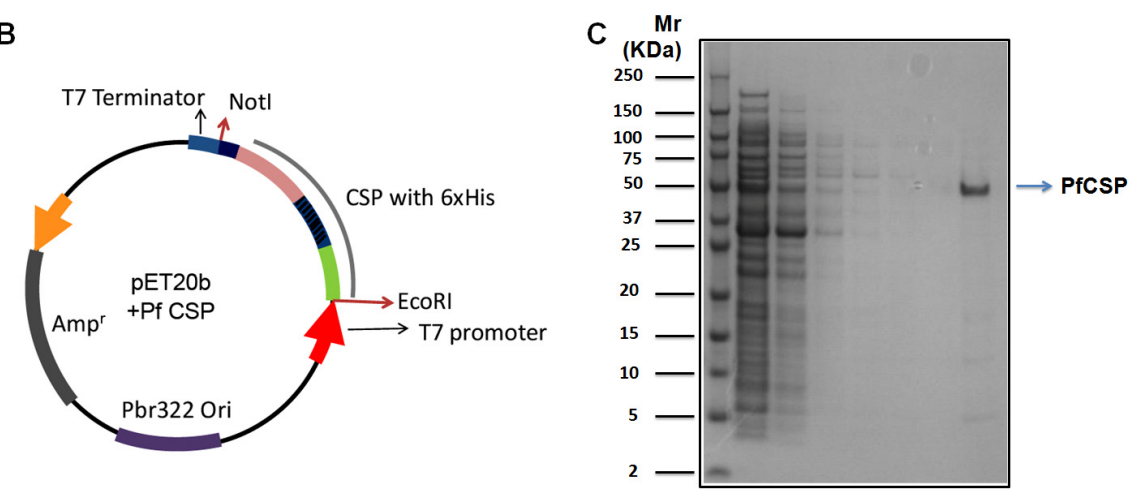

Figure 1. Expression and purification of a recombinant $P$. falciparum circumsporozoite protein (PfCSP). (A) Schematic representation of the recombinant PfCSP. Pf CSP coding sequence excluding C-terminal glycosylphosphatidylinositol (GPI) anchor, composed of N-terminal, central repeat, and C-terminal regions, was fused with 6XHis tag at its C-terminus, and cloned into pET20b vector (Stratagene, La Jolla, CA, USA); (B) Schematic representation of the PfCSP expression plasmid in this study. The full length of PfCSP without GPI anchor was cloned into pET20b vector between EcoR I and Not I; (C) Expression and purification of a recombinant PfCSP from E. coli. The recombinant PfCSP was expressed in BL21 (DE3), and then purified by Ni-Affinity Chromatography. Lane 1, Protein marker; Lane 2, crude extract; Lane 3, flow through; Lane 4-7, washes; Lane 8, elute. Data are representative from three independent experiments.

Table 1. The titers of the PfCSP-specific mAbs *.

\begin{tabular}{cccc}
\hline Name of the $\mathbf{m A b}$ & Titer (IFA) & Titer (ELISA) & Subclass \\
\hline 2A10 & $40 \mathrm{ng} / \mathrm{mL}$ & $10 \mathrm{ng} / \mathrm{mL}$ & $\mathrm{IgG2a}$ \\
$4 \mathrm{C} 6$ & $80 \mathrm{ng} / \mathrm{mL}$ & $1 \mu \mathrm{g} / \mathrm{mL}$ & $\mathrm{IgG1}$ \\
2D4 & $80 \mathrm{ng} / \mathrm{mL}$ & $500 \mathrm{ng} / \mathrm{mL}$ & $\mathrm{IgG1}$ \\
$3 \mathrm{C} 2$ & $10 \mathrm{ng} / \mathrm{mL}$ & $1 \mathrm{ng} / \mathrm{mL}$ & $\mathrm{IgG2b}$ \\
$4 \mathrm{C} 1$ & $328 \mu \mathrm{gg} / \mathrm{mL}$ & $200 \mathrm{ng} / \mathrm{mL}$ & $\mathrm{IgG} 2 \mathrm{~b}$ \\
3C1 & $5 \mathrm{ng} / \mathrm{mL}$ & $5 \mathrm{ng} / \mathrm{mL}$ & $\mathrm{IgG3}$ \\
3D3 & $10 \mathrm{ng} / \mathrm{mL}$ & $2 \mathrm{ng} / \mathrm{mL}$ & IgG1 \\
\hline
\end{tabular}

* PfCSP: P. falciparum circumsporozoite protein; IgG: immunoglobulin G; IFA: immunofluorescence assay; mAb: monoclonal antibody. 


\subsection{Specificity of Anti-PfCSP $m A b s$}

The specificity of the mAbs has been explored by measuring their reaction with peptides covering PfCSP N-terminal, the central repeat, and C-terminal regions (Table 2). The mAbs 2D4, 4C1, and 4C6 recognized the PfCSP C-terminal region. The $\mathrm{mAbs} 3 \mathrm{C} 1,3 \mathrm{C} 2$, and $3 \mathrm{D} 3$ recognized the PfCSP central repeat region (Figure 2).

Table 2. Synthetic peptides representing PfCSP.

\begin{tabular}{|c|c|c|}
\hline Peptide ID \# & Sequence & Position \\
\hline 1 & MMRKLAILSVSSFLF & N-terminus \\
\hline 2 & SSFLFVEALFQEYQC & N-terminus \\
\hline 3 & QEYQCYGSSSNTRVL & $\mathrm{N}$-terminus \\
\hline 4 & NTRVLNELNYDNAGT & N-terminus \\
\hline 5 & DNAGTNLYNELEMNY & N-terminus \\
\hline 6 & LEMNYYGKQENWYSL & N-terminus \\
\hline 7 & NWYSLKKNSRSLGEN & $\mathrm{N}$-terminus \\
\hline 8 & SLGENDDGNNEDNEK & N-terminus \\
\hline 9 & EDNEKLRKPKHKKLK & N-terminus \\
\hline 10 & HKKLKQPADGNPDP & N-terminus \\
\hline 11 & NANPNVDPNANPNVD & Repeats \\
\hline 12 & NPNVDPNANPNVDPN & Repeats \\
\hline 13 & NVDPNANPNANPNAN & Repeats \\
\hline 14 & NPNANPNANPNANPN & Repeats \\
\hline 15 & NANPNANPNANPNAN & Repeats \\
\hline 16 & NANPNANPNANPNVD & Repeats \\
\hline 17 & NPNVDPNANPNANPN & Repeats \\
\hline 18 & NANPNANPNKNNQGN & Repeats \\
\hline 19 & NNQGNGQGHNMPNDP & C-terminus \\
\hline 20 & MPNDPNRNVDENANA & C-terminus \\
\hline 21 & ENANANSAVKNNNNE & C-terminus \\
\hline 22 & NNNNEEPSDKHIKEY & C-terminus \\
\hline 23 & HIKEYLNKIQNSLST & C-terminus \\
\hline 24 & NSLSTEWSPCSVTCG & C-terminus \\
\hline 25 & SVTCGNGIQVRIKPG & C-terminus \\
\hline 26 & RIKPGSANKPKDELD & C-terminus \\
\hline 27 & KDELDYANDIEKKIC & C-terminus \\
\hline 28 & EKKICKMEKCSSVFN & C-terminus \\
\hline 29 & SSVFNVVNSSIGLIM & C-terminus \\
\hline 30 & IGLIMVLSFLFLN & C-terminus \\
\hline 31 & AIAWAKARARQGLEW & Negative Control Peptide \\
\hline
\end{tabular}

A

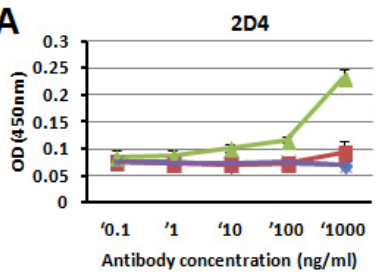

B
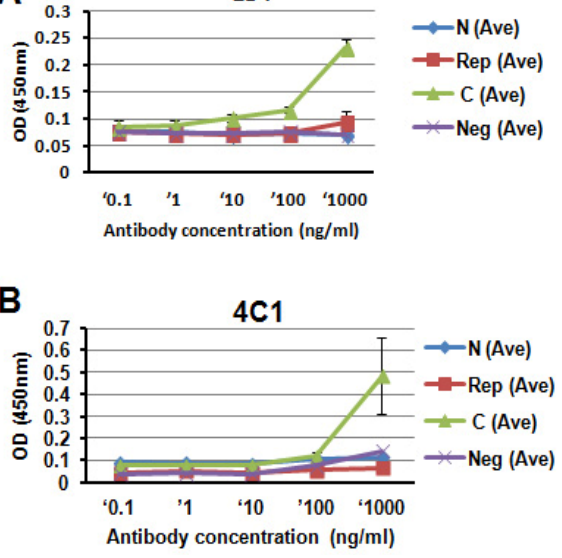

D

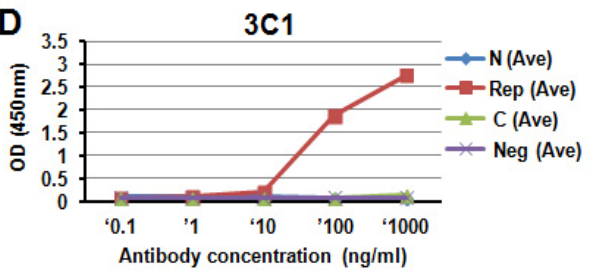

E

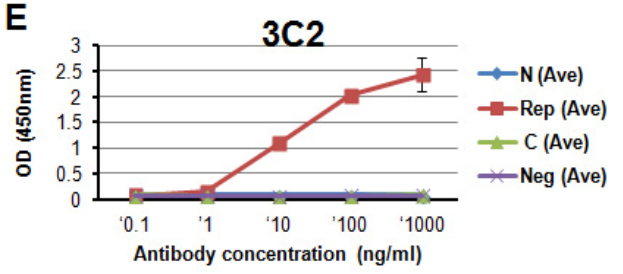

Figure 2. Cont. 

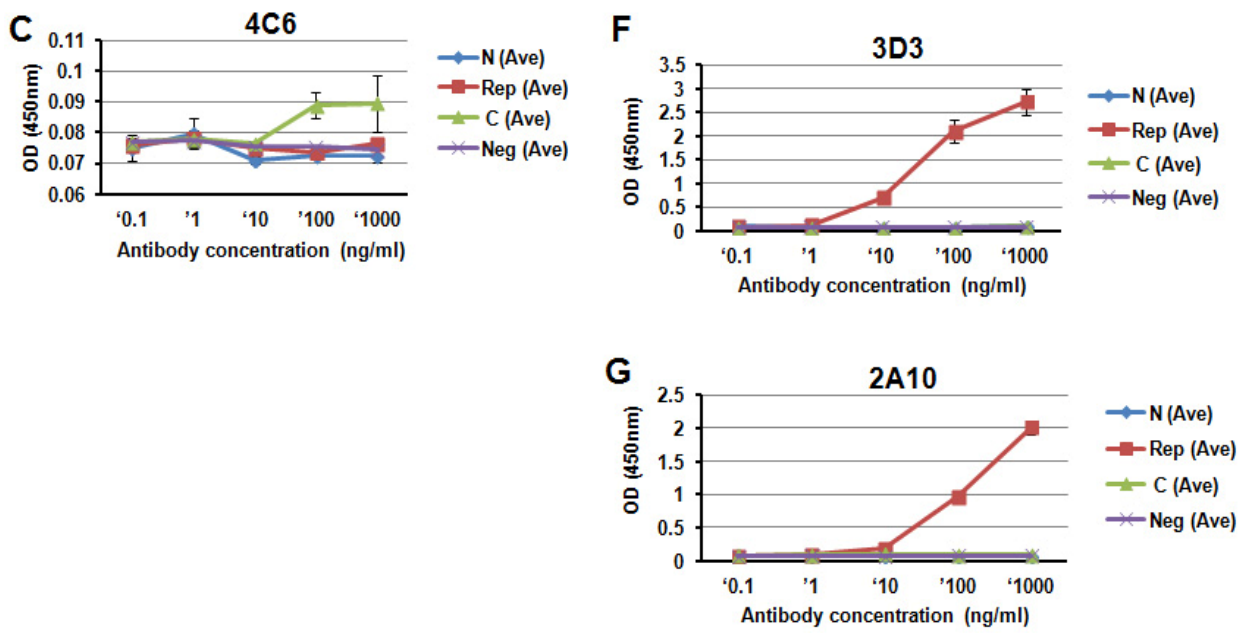

Figure 2. Specificity of anti-PfCSP monoclonal antibodies (mAbs) by enzyme-linked immunosorbent assay (ELISA). Peptides representing PfCSP N-terminal, central repeat, and C-terminal regions were used to evaluate specificity of anti-PfCSP mAbs (Table 1). (A), 2D4; (B), 4C1; (C),4C6; (D), 3C1; (E), 3C2; (F), 3D3; (G), 2A10. The mAb 2A10 was used as a positive control. ELISA was performed in duplicate.

Data are representative of three independent experiments. OD, Optical density.

\subsection{Titration of the PfCSP-Specific $m A$ bs}

The antibody titer was tested by enzyme-linked immunosorbent assay (ELISA) and immunofluorescence assay (IFA) (Table 1 and Figure 3). ELASA using peptides covering PfCSP showed that the titers of $\mathrm{mAbs}$ recognizing the PfCSP central repeat region were higher than those recognizing the PfCSP C-terminal region. The titers of the three mAbs recognizing the PfCSP central repeat were higher than the control 2A10 (3C2 > 3D3 > 3C1 > 2A10). IFA using the Plasmodium sporozoites expressing PfCSP [25] also showed that the titers of the mAbs recognizing the PfCSP central repeat were higher than those recognizing the PfCSP C-terminal region. The titer of the three mAbs recognizing the PfCSP central repeat were higher than the control 2A10 $(3 \mathrm{C} 1>3 \mathrm{D} 3=3 \mathrm{C} 2>2 \mathrm{~A} 10)$.

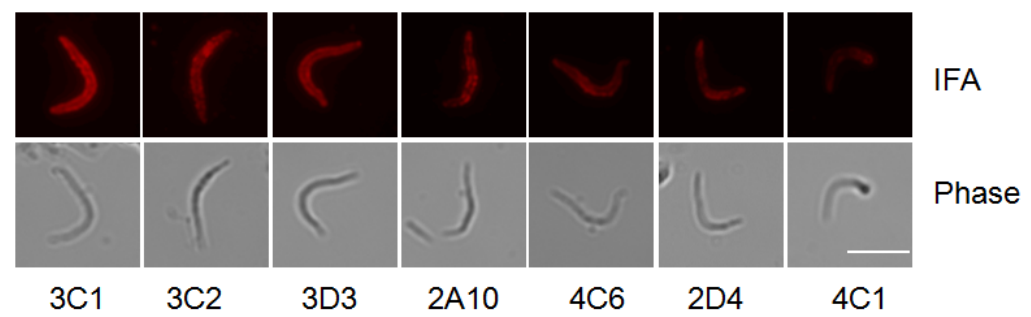

Figure 3. Immunofluorescence assays. PfCSP/Py (a P. yoelii parasite bearing P. falciparum circumsporozoite protein) salivary gland sporozoites [25] were incubated with $160 \mathrm{ng} / \mathrm{mL}$ mAbs, except $4 \mathrm{C} 1$ at $328 \mu \mathrm{g} / \mathrm{mL}$, followed by incubation with Alexa Fluor 594 goat anti-mouse $\operatorname{IgG}(\mathrm{H}+\mathrm{L})$ antibody.

\subsection{Protection of the PfCSP mAbs against PfCSP/Py Sprozoite Challenge}

We then examined the protection of the PfCSP mAbs against malaria sporozoite challenge in vitro and in vivo. For the malaria sporozoite challenges, we used the highly infectious hybrid PfCSP/Py sporozoite, which is based on rodent $P$. yoelii parasite and its CSP is replaced by the full-length of CSP from $P$. falciparum [25]. We found that $\mathrm{mAb} 3 \mathrm{C} 1,3 \mathrm{C} 2$, and 3D3 significantly inhibited the parasite development in Hepa 1-6 cells compared with 2A10, which is an effective mouse mAb specific for the PfCSP central repeat $[19,23]$ (Figure 4). This was in agreement with the in vivo neutralization assay (Table 3 and Figure 5). Fifty $\mu \mathrm{g}$ of 3C1, 3C2, and 3D3 completely protected the mice from PfCSP/Py 
sporozoite challenge. The protective effect of $3 \mathrm{C} 1,3 \mathrm{C} 2$, and $3 \mathrm{D} 3$ were better than the previously generated $\mathrm{mAb} 2 \mathrm{~A} 10$. Even $5 \mu \mathrm{g}$ of $3 \mathrm{C} 1$ partially protected the challenged mice compared to the $\mathrm{mAb} 2 \mathrm{~A} 10$.

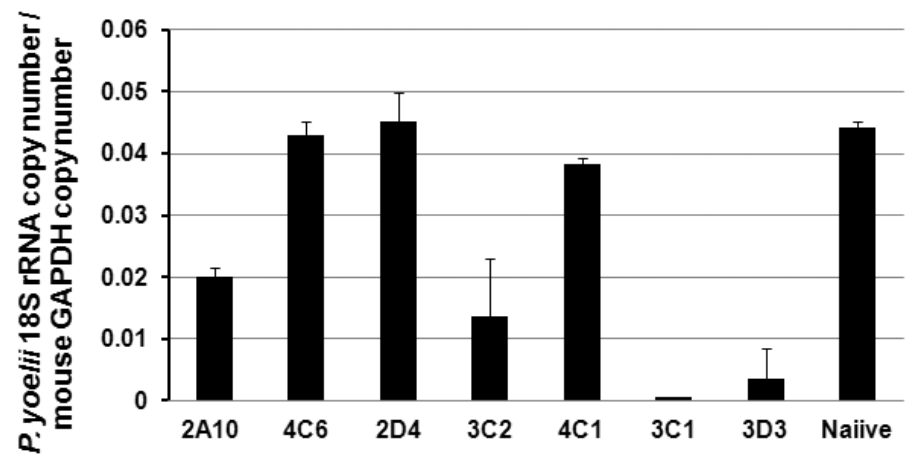

Figure 4. In vitro neutralization assay. $2 \times 10^{4} \mathrm{PfCSP} /$ Py sporozoites were pre-incubated with $100 \mu \mathrm{g}$ of each $\mathrm{mAb}$, and then added to Hepa1-6 cells. Forty-two hours post infection, liver stage parasite burden wear measured by $P$. yoelii $18 \mathrm{~S}$ rRNA/mouse glyceraldehyde 3-phosphate dehydrogenase (GAPDH). Naive mouse serum was used as control. The in vitro neutralization assay was performed in triplicate. Data are representative of two independent experiments.

Table 3. In vivo neutralization assay.

\begin{tabular}{ccccccccc}
\hline Amount of $\mathbf{m A b}$ & \multicolumn{4}{c}{$\mathbf{5} \boldsymbol{\mu g}$} \\
\hline Days Post Challenge & Day 3 & Day $\mathbf{4}$ & Day $\mathbf{5}$ & Day 14 & Day 3 & Day 4 & Day 5 & Day 14 \\
\hline 2A10 & $0 *$ *\# & 4 & 5 & 5 & 0 & 0 & 3 & 3 \\
4C6 & 0 & 5 & 5 & 5 & 0 & 1 & 4 & 4 \\
2D4 & 0 & 4 & 5 & 5 & 0 & 0 & 3 & 3 \\
3C2 & 0 & 1 & 5 & 5 & 0 & 0 & 0 & 0 \\
4C1 & 0 & 5 & 5 & 5 & 0 & 3 & 4 & 4 \\
3C1 & 0 & 1 & 4 & 4 & 0 & 0 & 0 & 0 \\
3D3 & 0 & 2 & 5 & 5 & 0 & 0 & 0 & 0 \\
Naiive & 0 & 5 & 5 & 5 & 0 & 5 & 5 & 5 \\
\hline
\end{tabular}

* Five mice per group. ${ }^{\#}$ The number of infected mice.

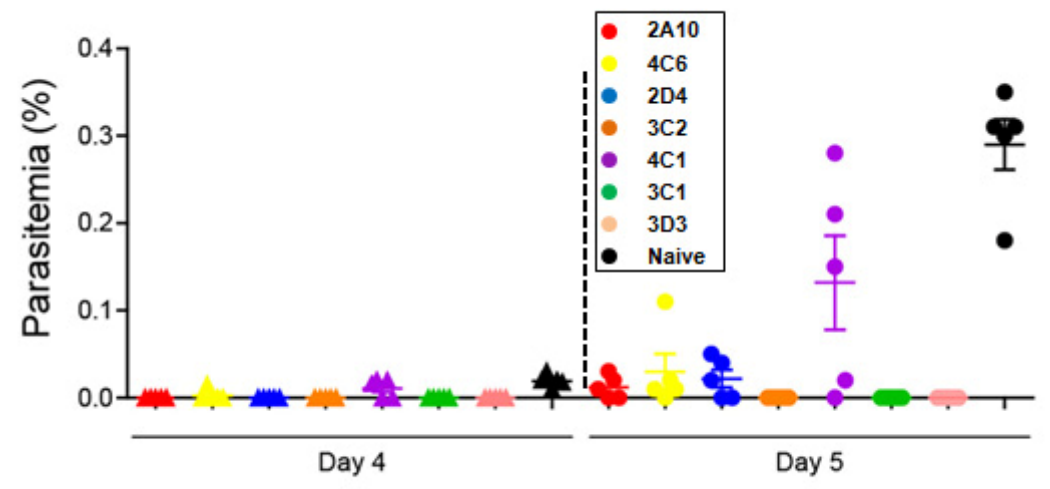

Days post PfCSP/Py sporozoite challenge

Figure 5. Parasitemia of mice in the neutralization assay. Fifty PfCSP/Py sporozoites were incubated with $50 \mu \mathrm{g} \mathrm{mAbs}$ followed by i.v. injection into BALB/c mice (five mice per group). Parasitemia were counted by Giemsa stains of mouse tail blood followed by microscopy. Data are parasitemia of the mice four and five days post challenge. Naive mice were i.v. injected with $50 \mathrm{PfCSP} / \mathrm{Py}$ sporozoites as positive controls. 


\section{Discussion}

The CSP consists of the N-terminal flanking region, the central region that contains repetitive immunodominant B-cell epitopes, and the C-terminal flanking region that contains multiple T-cell epitopes. The N-terminus of the CSP is proteolytically processed during the sporozoite invasion into host cells $[15,16]$. This may explain why we did not obtain specific antibodies against the $\mathrm{N}$-terminus. The abundant NANP repeats present within the central region are likely to contribute to the high neutralization efficacies of the mAbs against PfCSP central repeat region, as previously published [26,27]. In fact, mAbs, which recognize the PfCSP central repeat region, have been shown to exert a potent neutralization activity against the sporozoites [26,27]. All the mAbs 3C1, 3C2, 3D3, and 2A10, recognize the central repeat region of the PfCSP. Fifty $\mu \mathrm{g}$ of the novel mAbs $3 \mathrm{C} 1,3 \mathrm{C} 2$, and 3D3 completely protected the mice from PfCSP/Py sporozoites challenge; while the reference $\mathrm{mAb} 2 \mathrm{~A} 10$ only partially protected the mice. A likely explanation is that the native structure of the central repeats of the CSP is not in a random coil state, and the repeat region is predicted to form a rod-like structure [28]. It is speculated that these $\mathrm{mAbs}$ recognize structurally different epitopes coded by NANP repeat, resulting in different protection efficacies. The titers $(3 \mathrm{C} 1>3 \mathrm{D} 3=3 \mathrm{C} 2>2 \mathrm{~A} 10)$ of these novel mAbs determined by IFA using a whole malaria parasite (sporozoite), as an antigen, corroborate their protection efficacies in vitro $(3 \mathrm{C} 1>3 \mathrm{D} 3>3 \mathrm{C} 2>2 \mathrm{~A} 10)$, as well as in mice $(3 \mathrm{C} 1>3 \mathrm{D} 3=$ $3 \mathrm{C} 2>2 \mathrm{~A} 10)$. These indicate that $\mathrm{mAbs}$ having higher titers against the native from of the CSP expressed by sporozoites exert higher protection efficacies.

Synthesized peptides and sporozoites were used in ELISA and IFA, respectively, to determine the antibody titers. Sporozoites express a native form of the PfCSP, whereas synthesized peptides represent the primary structure of PfCSP. B-cell epitopes are typically classified as either linear epitopes or conformational epitopes, which constitute the spatially folded amino acids and lie far away in the primary sequence. The difference seen by ELISA and IFA may reflect the structural properties of unique B-cell epitopes recognized by our mAbs.

Over the past few years, there has been growing interest in use of vectored immunoprophylaxis to protect hosts from HIV. Vectored immunoprophylaxis is based on adeno-associated virus (AAV) as a vehicle for generating the existing anti-HIV neutralizing antibodies in humans [29,30]. Recently vectored immunoprophylaxis has been utilized for other diseases including malaria and colorectal cancer [12,31]. This new tool requires potent neutralizing antibodies. Although human monoclonal antibodies against PfCSP have been generated, only one mouse mAb against PfCSP, 2A10, has been used as a gold standard $\mathrm{mAb}$ for more than three decades. It is noteworthy that a few new mouse mAbs against PfCSP, which we generated in this study, are found to be more potent than 2A10. Therefore, we believe it is important to assess the characteristics of these newly generated mAbs before humanizing them for the purpose of clinical applications, such as a vectored immunoprophylaxis, in the future. Moreover, the mouse mAbs generated in this study are useful tools for the study of PfCSP in a mouse model.

\section{Conclusions}

In summary, here we report a generation of novel $\mathrm{mAbs}$ specific against the CSP from P. falciparum. The mAbs 2D4, 4C1, and 4C6 recognize the C-terminal region of PfCSP. The mAbs 3C1, 3C2, and 3D3 recognize the central repeat region of PfCSP, and their titers and protection efficacies are higher than 2A10, which has been widely used as a gold standard antibody against PfCSP.

Acknowledgments: This work was supported by grants from NIH AI073658 and AI081510 (both to M.T.).

Author Contributions: M.T. conceived and designed the experiments; M.Z., R.M., U.R., and T.S. performed the experiments and analyzed the data; M.Z. and M.T. wrote the paper.

Conflicts of Interest: The authors declare no conflict of interest. 


\section{References}

1. World Health Organization. World Malaria Report; World Health Organization: Geneva, Switzerland, 2015.

2. Cheah, P.Y.; White, N.J. Antimalarial mass drug administration: Ethical considerations. Int. Health 2016, 8, 235-238. [CrossRef] [PubMed]

3. Ochomo, E.; Chahilu, M.; Cook, J.; Kinyari, T.; Bayoh, N.M.; West, P.; Kamau, L.; Osangale, A.; Ombok, M.; Njagi, K.; et al. Insecticide-treated nets and protection against insecticide-resistant malaria vectors in western Kenya. Emerg. Infect. Dis. 2017, 23, 758-764. [CrossRef] [PubMed]

4. Mashauri, F.M.; Manjurano, A.; Kinung'hi, S.; Martine, J.; Lyimo, E.; Kishamawe, C.; Ndege, C.; Ramsan, M.M.; Chan, A.; Mwalimu, C.D.; et al. Indoor residual spraying with micro-encapsulated pirimiphos-methyl (Actellic (R) 300CS) against malaria vectors in the Lake Victoria basin, Tanzania. PLoS ONE 2017, 12, e0176982. [CrossRef] [PubMed]

5. Matuschewski, K. Vaccines against malaria-still a long way to go. FEBS J. 2017. [CrossRef] [PubMed]

6. Alout, H.; Labbe, P.; Chandre, F.; Cohuet, A. Malaria vector control still matters despite insecticide resistance. Trends Parasitol. 2017, 33, 610-618. [CrossRef] [PubMed]

7. Antony, H.A.; Parija, S.C. Antimalarial drug resistance: An overview. Trop. Parasitol. 2016, 6, 30-41. [PubMed]

8. Barik, T.K. Antimalarial drug: From its development to deface. Curr. Drug Discov. Technol. 2015, 12, $225-228$. [CrossRef] [PubMed]

9. Rts, S.C.T.P. Efficacy and safety of RTS,S/AS01 malaria vaccine with or without a booster dose in infants and children in Africa: Final results of a phase 3, individually randomised, controlled trial. Lancet 2015, 386, $31-45$.

10. Agnandji, S.T.; Lell, B.; Fernandes, J.F.; Abossolo, B.P.; Methogo, B.G.; Kabwende, A.L.; Adegnika, A.A.; Mordmuller, B.; Issifou, S.; Kremsner, P.G.; et al. A phase 3 trial of RTS,S/ AS01 malaria vaccine in African infants. N. Engl. J. Med. 2012, 367, 2284-2295. [PubMed]

11. Kazmin, D.; Nakaya, H.I.; Lee, E.K.; Johnson, M.J.; van der Most, R.; van den Berg, R.A.; Ballou, W.R.; Jongert, E.; Wille-Reece, U.; Ockenhouse, C.; et al. Systems analysis of protective immune responses to RTS,S malaria vaccination in humans. Proc. Natl. Acad. Sci. USA 2017. [CrossRef] [PubMed]

12. Deal, C.; Balazs, A.B.; Espinosa, D.A.; Zavala, F.; Baltimore, D.; Ketner, G. Vectored antibody gene delivery protects against Plasmodium falciparum sporozoite challenge in mice. Proc. Natl. Acad. Sci. USA 2014, 111, 12528-12532. [CrossRef] [PubMed]

13. Kumar, K.A.; Sano, G.; Boscardin, S.; Nussenzweig, R.S.; Nussenzweig, M.C.; Zavala, F.; Nussenzweig, V. The circumsporozoite protein is an immunodominant protective antigen in irradiated sporozoites. Nature 2006, 444, 937-940. [CrossRef] [PubMed]

14. Ferguson, D.J.; Balaban, A.E.; Patzewitz, E.M.; Wall, R.J.; Hopp, C.S.; Poulin, B.; Mohmmed, A.; Malhotra, P.; Coppi, A.; Sinnis, P.; et al. The repeat region of the circumsporozoite protein is critical for sporozoite formation and maturation in Plasmodium. PLoS ONE 2014, 9, e113923. [CrossRef] [PubMed]

15. Coppi, A.; Pinzon-Ortiz, C.; Hutter, C.; Sinnis, P. The Plasmodium circumsporozoite protein is proteolytically processed during cell invasion. J. Exp. Med. 2005, 201, 27-33. [CrossRef] [PubMed]

16. Coppi, A.; Natarajan, R.; Pradel, G.; Bennett, B.L.; James, E.R.; Roggero, M.A.; Corradin, G.; Persson, C.; Tewari, R.; Sinnis, P. The malaria circumsporozoite protein has two functional domains, each with distinct roles as sporozoites journey from mosquito to mammalian host. J. Exp. Med. 2011, 208, 341-356. [CrossRef] [PubMed]

17. Nardin, E.H.; Oliveira, G.A.; Calvo-Calle, J.M.; Castro, Z.R.; Nussenzweig, R.S.; Schmeckpeper, B.; Hall, B.F.; Diggs, C.; Bodison, S.; Edelman, R. Synthetic malaria peptide vaccine elicits high levels of antibodies in vaccinees of defined HLA genotypes. J. Infect. Dis. 2000, 182, 1486-1496. [CrossRef] [PubMed]

18. Stoute, J.A.; Slaoui, M.; Heppner, D.G.; Momin, P.; Kester, K.E.; Desmons, P.; Wellde, B.T.; Garcon, N.; Krzych, U.; Marchand, M. A preliminary evaluation of a recombinant circumsporozoite protein vaccine against Plasmodium falciparum malaria. N. Engl. J. Med. 1997, 336, 86-91. [CrossRef] [PubMed]

19. Anker, R.; Zavala, F.; Pollok, B.A. VH and VL region structure of antibodies that recognize the (NANP)3 dodecapeptide sequence in the circumsporozoite protein of Plasmodium falciparum. Eur. J. Immunol. 1990, 20, 2757-2761. [CrossRef] [PubMed] 
20. Charoenvit, Y.; Mellouk, S.; Cole, C.; Bechara, R.; Leef, M.F.; Sedegah, M.; Yuan, L.F.; Robey, F.A.; Beaudoin, R.L.; Hoffman, S.L. Monoclonal, but not polyclonal, antibodies protect against Plasmodium yoelii sporozoites. J. Immunol. 1991, 146, 1020-1025. [PubMed]

21. Persson, C.; Oliveira, G.A.; Sultan, A.A.; Bhanot, P.; Nussenzweig, V.; Nardin, E. Cutting edge: A new tool to evaluate human pre-erythrocytic malaria vaccines: Rodent parasites bearing a hybrid Plasmodium falciparum circumsporozoite protein. J. Immunol. 2002, 169, 6681-6685. [CrossRef] [PubMed]

22. Foquet, L.; Hermsen, C.C.; van Gemert, G.J.; Van Braeckel, E.; Weening, K.E.; Sauerwein, R.; Meuleman, P.; Leroux-Roels, G. Vaccine-induced monoclonal antibodies targeting circumsporozoite protein prevent Plasmodium falciparum infection. J. Clin. Investig. 2014, 124, 140-144. [CrossRef] [PubMed]

23. Zavala, F.; Cochrane, A.H.; Nardin, E.H.; Nussenzweig, R.S.; Nussenzweig, V. Circumsporozoite proteins of malaria parasites contain a single immunodominant region with two or more identical epitopes. J. Exp. Med. 1983, 157, 1947-1957. [CrossRef] [PubMed]

24. Bruna-Romero, O.; Hafalla, J.C.R.; Gonzalez-Aseguinolaza, G.; Sano, G.; Tsuji, M.; Zavala, F. Detection of malaria liver-stages in mice infected through the bite of a single Anopheles mosquito using a highly sensitive real-time PCR. Int. J. Parasitol. 2001, 31, 1499-1502. [CrossRef]

25. Zhang, M.; Kaneko, I.; Tsao, T.; Mitchell, R.; Nardin, E.H.; Iwanaga, S.; Yuda, M.; Tsuji, M. A highly infectious Plasmodium yoelii parasite, bearing Plasmodium falciparum circumsporozoite protein. Malar. J. 2016, 15, 201. [CrossRef] [PubMed]

26. Potocnjak, P.; Yoshida, N.; Nussenzweig, R.S.; Nussenzweig, V. Monovalent fragments (Fab) of monoclonal antibodies to a sporozoite surface antigen $(\mathrm{Pb} 44)$ protect mice against malarial infection. J. Exp. Med. 1980, 151, 1504-1513. [CrossRef] [PubMed]

27. Gysin, J.; Barnwell, J.; Schlesinger, D.H.; Nussenzweig, V.; Nussenzweig, R.S. Neutralization of the infectivity of sporozoites of Plasmodium knowlesi by antibodies to a synthetic peptide. J. Exp. Med. 1984, 160, 935-940. [CrossRef] [PubMed]

28. Plassmeyer, M.L.; Reiter, K.; Shimp, R.L., Jr.; Kotova, S.; Smith, P.D.; Hurt, D.E.; House, B.; Zou, X.; Zhang, Y.; Hickman, M.; et al. Structure of the Plasmodium falciparum circumsporozoite protein, a leading malaria vaccine candidate. J. Biol. Chem. 2009, 284, 26951-26963. [CrossRef] [PubMed]

29. Balazs, A.B.; Ouyang, Y.; Hong, C.M.; Chen, J.; Nguyen, S.M.; Rao, D.S.; An, D.S.; Baltimore, D. Vectored immunoprophylaxis protects humanized mice from mucosal HIV transmission. Nat. Med. 2014, 20, $296-300$. [CrossRef] [PubMed]

30. Balazs, A.B.; Chen, J.; Hong, C.M.; Rao, D.S.; Yang, L.; Baltimore, D. Antibody-based protection against HIV infection by vectored immunoprophylaxis. Nature 2012, 481, 81-84. [CrossRef] [PubMed]

31. Hu, S.; Dai, H.; Li, T.; Tang, Y.; Fu, W.; Yuan, Q.; Wang, F.; Lv, G.; Lv, Y.; Fan, X.; et al. Broad RTK-targeted therapy overcomes molecular heterogeneity-driven resistance to cetuximab via vectored immunoprophylaxis in colorectal cancer. Cancer Lett. 2016, 382, 32-43. [CrossRef] [PubMed]

(C) 2017 by the authors. Licensee MDPI, Basel, Switzerland. This article is an open access article distributed under the terms and conditions of the Creative Commons Attribution (CC BY) license (http:/ / creativecommons.org/licenses/by/4.0/). 